\title{
Teachers' Training in the Intercultural Dialogue and Understanding: Focusing on the Education for a Sustainable Development
}

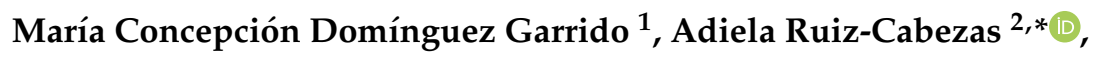 \\ María Castañar Medina Domínguez ${ }^{3, *}$, María Cecilia Loor Dueñas ${ }^{2}$, Eufrasio Pérez Navío ${ }^{4}$ (i) \\ and Antonio Medina Rivilla ${ }^{1}$ \\ 1 Department of Didactics, Faculty of Education, School Organization and Special Didactics, \\ Universidad Nacional de Educación a Distancia-UNED, Calle Juan del Rosal, 14, 28040 Madrid, Spain; \\ cdominguez@edu.uned.es (M.C.D.G.); amedina@edu.uned.es (A.M.R.) \\ 2 Faculty of arts and humanities, Institute for Research and Innovation in Social Sciences, Humanistic Studies \\ and Art, Universidad Católica de Santiago de Guayaquil-UCSG, Av. Pdte. Carlos Julio Arosemena Tola, \\ Guayaquil 090615, Ecuador; maria.loor@cu.ucsg.edu.ec \\ 3 Faculty of Social Sciences, Universidad Nebrija, C. de Sta. Cruz de Marcenado, 27, 28015 Madrid, Spain \\ 4 Department of Pedagogy, Faculty of Education, Universidad de Jaén, Campus Las Lagunillas, s/n, \\ 23071 Jaén, Spain; epnavio@ujaen.es \\ * Correspondence: adiruiz@madrid.uned.es (A.R.-C.); tatinamedina@invi.uned.es (M.C.M.D.)
}

Received: 29 September 2020; Accepted: 25 November 2020; Published: 27 November 2020

\begin{abstract}
The present research is embedded in the professional development and research line, and in the needs of secondary education and first-year university teachers. Evidencing the importance of teachers' professional training to include specific adaptations and skills on both the intercultural dialogue and understanding - often called Intercultural Competence-is fundamental because of the direct impact for the sustainable development of human beings, groups, and ecosystems. An extensive investigation of the role played by each of the main competencies linked to the following intercultural dimensions was performed: Professional Identity, Ethics and Axiology, Methodology, and Inclusive Education. The integrated methodology used was a cross-study of data, performed after the obtention of a three-cornered evaluation of results collected in focus groups, interviews, and questionnaires. Findings showed the impact of the intercultural dialogue and understanding in education patterns for the sustainable development of society. Other outputs also underlined the relevance of setting up a new ecology of forms, knowledge, attitudes, and educational meanings, further used to update teachers and students' training in sustainable ecology and cultural diversity. Progress made in these complementary competencies—Professional Identity, Ethics and Axiology, Methodology—were appraised by teachers participating in the present study; the latter showing an increased interest and demand for the intercultural competence, after increasing their proficiency in the other complementary competencies.
\end{abstract}

Keywords: teachers' training; teachers' competencies; intercultural dialogue; education for sustainable development; professional development

\section{Introduction}

Keeping teachers updated is one of the main priorities for teachers themselves and for educational systems too, regardless of perspectives or objectives marked by international organizations, teachers 'associations, or networks. In this way, considering the fundamental needs for capacity development is becoming a priority to empower professionals facing an ever-changing world, characterized by vast dependencies, globalization, and uncertainty. Education on the establishment of 
new dialogue patterns with and between diversified cultural partners, migrating identities, and human beings is key to foster genuine cooperation and sustainable planet management as an objective [1-5].

The 2020-2030 Agenda presents the main objectives to witness the emergence of worldwide consciousness-raising patterns and commitments. Among others, "equal rights for all humans, their integral education, respect of diversity and differentiated growth for all human beings and groups" are listed. This statement underlines the value and role played by human beings as such, deriving from their very nature and ecological beliefs. The acceptance of this educational commitment framed in the specific and rich area of educational training is at the very core of the debate. Every student and culture are part of an educational community and acts as true protagonists, in terms of equal rights, universalization of education, or respect and understanding. Changing educational and attention patterns in schools is the main responsibility of these centers, and training professionals are a key asset in such a transformation.

Teachers' professional developments and strategies, used to give a proper answer to every culture and student, has been researched in many countries. The following review of the published material by the scientific community on the subject sets forth the existence-in Europe and on other continents-of shifting ecological environments and diverse societies or cultures, with people of different origins willingly facing the challenges of a new and sustainable world.

The present research is centered on teachers' training and development of competencies in dialogue and intercultural understanding [6,7]. The consolidation of practical theories and models summarizing the main approaches on cultural understanding and sharing has been carried out on: Getting to know, think [8,9], and build educational processes, the use of complementary and inter-subjective qualities, some increasingly creative and intense empathy patterns, the sense derived from the training knowledge based on empathy, respect of diversity, and project designs or training actions [5].

The core of the intercultural dialogue competence is included in the dialogic principle [10-12], together with that of the specific building of new virtual environments for intercultural education $[13,14]$.

The classical dimensions of competencies [15-17] acquire a more specific tone when training includes some practices, where the newly acquired knowledge is applied. When this information is applied to experience, as defined by Dewey, both the thinking and learning process are completed because all fully participate. The new competence is therefore formed by every teacher or group and analyzed from visions. The intercultural competency combines knowledge and empathy-both characteristics of human beings-with closeness and understanding, actions, or cooperation [18,19]. For them, such a competence is based on a civic and communicative culture that capacitates teachers to perform global thinking and is completed by local-style action.

The intercultural competence requires specific qualities that are represented as complementary: Namely, the intercultural experience, motivation, global attitude, and ability to listen appropriately. These contribute to an action style based on a global perception of people, although they also attend both their individualities and the stability of their traditional cultural identities.

As such, [20] exposes that the holistic and contextual knowledge of other cultures provide for their understanding. They evidence a mutual enrichment, allowing for a better comprehension that is based on learning and interpretation processes, giving way to more fruitful encounters and open or shared reflections.

The present research is looking into the main components and knowledge required by twenty-first century teachers, in diverse contexts, with a particular insight on the Spanish experience. The need for a professionalization of teachers' training and the inclusion of extended learning-to-know-methods and tools that seem to play a determinant role when trying to understand people and cultures. Within a particular group, every human being is identified openly by others culturally. Focus was set on the most important dimension for teachers' training on these aspects to help them learn to do/act within the group/schools and improve their understanding of nuclear tensions [21,22].

Connecting the comprehension of knowledge and the action is a new dimension of modern education. True harmonization between both concepts is synthetized in teachers' own identity. It is 
through the extensive dialogue with other human beings that people learn to reject all prejudice, distance, and differentiation based on a specific behavior. This substantial ethical aspect claims for a new proximity, under a common framework [23], that is based on some authentic process and commitments that are part of an integral humanization of education.

This model justification is underlined by specific components evidenced by [24] on leadership attributes-that are in accordance with the emotional intelligence development-, new coaching styles, and empathy abilities developed by trainers and educational programs. Every teacher is then considered as a committed and critical ally in this line. Teachers participating in the study, outlined the need for greater involvement and assumption of their responsibilities-following their own training/professional competencies-to foment dialogue and understanding between students or families and attain some emotional balance together with a real proximity of people and cultures.

Training in transformational and instructive leadership $[25,26]$ has meant a significant support for research participants because it positively impacted on the improvement of results, and fomented significant progress in both dialogue and understanding of people, usual authentic leaders in uncertainty contexts.

This capacity development approach has also been broadened to assume the illustration challenge of the true commitment with people and cultures; [27-29] believe that when every teacher's/professional educator's ecosystem or concrete working position is potentiated fully, learning can be achieved - taking into consideration the know-how and location-by using a more extended expertise and commitment (professional ethics). Leadership is also evidenced [30] to be a creative synthesis of complementary aspects and elements that are truly fomenting a new style of human relationships. Teachers are leaders to be used as cultural understanding experts and problem-solving triggers. They can help with the real integration of projects between human beings and the follow up of new cooperative, understanding concepts. The provision of a permanent research line, with shared learning models and forms, based on dialogue throughout life, is then essential.

The present study, following the results published by the Comprofesu (2016-2020) and UCSG (2018-2019) projects, has focused on four complementary competencies shown to reinforce dialogue and intercultural understanding skills:

- Professional Identity.

- Ethical.

- Methodological.

- Professional commitment to dialogue and intercultural understanding.

The fields of such competencies are quite extensive and complex when trying to attain a proper development of the intercultural dialogue. A decision was made to research on these, however, to determine their exact contribution as to the intercultural competence, during the teaching-learning and professional development process.

Research conducted in the field have previously underlined the necessity for teachers to apprehend new training challenges, that are considered as essential to achieve the intercultural understanding competence.

\subsection{The Professional Identity Dimensions}

Ref. [31] highlighted this dimension as being a substantive core of teachers' training, considering the state of satisfaction, creative acceptation of the task, and integral and responsible execution, together with a permanent overcoming type.

Ref. [32] commented on the components of reflexive education, identifying as fundamental the following: Level of consciousness achieved by teachers; significance and impact with which they assume and perform their profession: high degree of satisfaction with their profession [33], evidenced that the performance and quality of the intercultural teaching-learning process are associated with the acceptation and intensification of their professional life, which is reflected in dialogue and cooperation 
levels with families and students of diverse cultures represented in the group. The authors express that "the selection of the most relevant training experiences for each teacher, are to represent an object for reflexion and professional development, that is to be analysed further and converted into a basis for knowledge and consolidation of their own teaching innovative process". Identification with professional development is higher when teachers assume this is a personal process they can share and develop; when they realize, they can delve on their own knowledge patterns to try and understand the educational events they experience.

Ref. [34] underline that professional development programs for teachers have increased the research competence in their daily practice and activity. They have allowed for improved relationships with other teachers within the educational community they belong to. They feel leaders tend to resolve the challenges and contradictions that such programs have not yet managed to resolve.

Ref. [35] examines the associations between teachers, their emotional wellbeing, working contexts, and resilience. He considers as key components their sense of professional identity, professionalism, and perceived effectiveness given the existing challenges and pressures they face to respond to some increasingly high expectations and demands. Reviewed contexts account for changes in the nature of teachers' professional orientation work and challenges in their existing professional identities [36].

Ref. [37] emphasizes the value of the socialization process delivered by teachers' trainers and confirm their positive impact on the learning-teaching proceedings. They also find fundamental to work on the subjective visions and intensified build-ups of the professional identity competence, to support intercultural dialogue and understanding.

Comprehension between people of diverse cultural origins is based on an open-minded vision-provided and developed by teachers-that is consistent with their expectations and needs. Singularly, they have to provide some existential balance and harmony to increase the development of migrants' identity. These are necessary to attain the objective of a fertile interaction and build up, performed in a satisfying professional environment, while always bearing in mind the importance of the mutual enrichment generated by these new insights and common perspectives [38].

The research conducted by [39] revealed that teachers' professional identity and its underpinning constructs—such as emotions, job satisfaction, professional commitment, autonomy, and confidence-were constantly challenged and negotiated within the changing educational setting. Contextual and professional factors like work intensification, lack of training and resources, lack of respect, and negligence of teachers in previous experiences, their ideologies, values and beliefs were found to affect teachers' identity and consequently intercultural policy enactment. Professional identity complexity needs be taken into account by policymakers because teachers are in the front line to embrace, reinterpret, and develop educational programs. The way teachers understand, adjust, perceive, and act according to educational policies also affects these policies and interacts with them by challenging the existing identities.

The study published by [40] on the development of identity in the university context showed that several factors contribute to the development of teachers' identity. While contact with students and staff training programs proved to have a strengthening effect on this identity, it seemed to be having a constraining effect within the context of Higher Education. Furthermore, the direct impact of work environment itself had either strengthening or constraining effects on it, these depending mostly on the positive or negative valuation of the team itself. Five psychological processes were found to affect such a development: A sense of appreciation, a sense of connectedness, a sense of competence, a sense of commitment, and imagining a future career trajectory. The findings suggest that developing teachers' identity in Higher Education is not an easy task. The empowerment of University teachers needs to be based on a reward system, teaching excellence programs and community build up strategies.

Professional identity is constructed gradually on knowledge and a permanent update of one's own culture. When teachers are conscious of the continuous challenges demanded by our complex and confused world, building up the intercultural dialogue competence and education, based on understanding, is only possible in a satisfactory environment. This is enabled using a common approach 
integrating a specific cultural knowledge and the full implication of participants. Teachers can then develop responsible improvements in their own deontological code. These are to be applied from their personal experiences and understanding of people to generate places and times for research on the meanings and interrelationship patterns that are based on empathy and understanding. This is fruitful when trying to discover the best teaching models and forms [41-44], because identity consolidation evidences an intensification and more significative implication of the intercultural dialogue.

\subsection{The Ethic-Axiological Dimension}

We included this dimension in the competence group because it represents the basic and true significance of human dispositions and feelings, when they are responsible and open to fruitful dialogue. Therefore, such a training component is included as a key competence for generic and professional development; it improves cultural understanding and enrichment because it accounts for the coherence of consolidated cultural values. This is a nuclear aspect when trying to understand different lifestyles, group structures, and milestones represented by scale values that are specific to every culture represented within the group, most particularly those related to identifying traits.

The ethical competence enables teachers to deepen their reflections and find the right arguments to answer every case they are confronted to. Professional actions are paramount to help them understand and grasp better their obligations. Questions on the importance of the moral process implied and the decision-making patterns are naturally raised when teachers foment intercultural understanding between people and cultures.

The ethical model has to prevail upon the theological one because the value of duties performed characterizes the action guidelines within communities and between people. Ref. [45] reminds us of the importance of identifying both the duties and norms to truly foster the growth of such educational routes.

This competence is characterized by the criteria and integral knowledge on which standards are built. Teachers really find it easier to perform their duties when these norms are clearly interpreted and assumed. However, what really makes a difference between professionals is when they identify adequately with and develop these rules during their educational practice. When they can assume these values and are ready to accept them as mature professionals. Such maturity is then evidenced because it contributes to the build-up of endorsed and justified principles and norms, with teachers' assumption of their paper in a meaningful society.

How can teachers improve the ethical competence? Do teachers consciously feel they are less tied to their sense of duty, and reflect less on why they need to perform educational actions based on empathy, dialogue, and intercultural understanding? Do teachers deepen their reflections on the positive role played by such intercultural understanding and links established between people?

Teachers' professional action is a decision-making process [41,45], though such decisions need be clearly supported by a project with a future, and based on instruments/means and resources. Limits are also to be established for a proper development; excessive competitivity must be moderated, all cultures are to be integrated, fully respecting the idiosyncrasy of each of them. During the process, teachers also face their own issues, demands, and challenges or complexities that are derived from situations like pandemics, for example. The 2020 pandemic has meant a new way to build relationships, projects, and understanding of limits between different cultures inside schools. In this line, [45] underlines the singular value of every student in his/her relationship with the teacher, considered as a fully entitled being and developed citizen in our permanently connected and open to dialogue 'globalized world'.

Ref. [46] suggests the application of bio-ethic principles to regulate professional activities since they affect teachers, clients, and society itself. It underlines the importance of consideration and consciousness of all teachers and the 'benefits' obtained through this professional challenge; since this practice is to be damage-less for participants, which means being committed to other people's wellness through the provision of help and protection for the benefit of society. 
The educational practice must be developed, acknowledged, and facilitated by other participants recognizing this expertise. This is when it can be fully exploited in its instructive and guiding aspects, where complete collaboration and mutual respect towards its expansion is fully represented in its cultural, social, and existential diversities. Reciprocity and necessary joint commitment are fundamental to develop training sessions that are oriented to the full understanding and empathic interaction between teachers and students. Both groups becoming aware of educational acts, used to enhance cultural diversity challenges and complex globalizing focus. Such a self-empowerment and respectful principle towards students, families, and society is to be completed with a sense of justice implicating a 'rational and supportive distribution of limited resources'.

In this line, teachers could be involved in activities aimed at developing their confidence and competences in teaching in intercultural environments, where cultural differences should not be ignored or minimized, but accepted, respected, and valued [47,48]. In particular, professional development experiences should impact teachers' knowledge and practical skills as well as the definition of their professional identities, in terms of beliefs, values, and attitudes towards classroom teaching activity [49].

Professional development in the field of intercultural education should include critical reflection on individual beliefs about the meanings of the word "culture", its impact on human relations, and the way it affects students and families' educational experience at school. It is crucial to encourage teachers to reflect on their attitudes and to discuss and negotiate them within the professional community which shares the same challenges [50-52].

Teachers need to provide for an authentic and pertinent reflection on educational models and practices because education is a fundamental right for all. Every human being and community are entitled to an integral education and needs to be represented using creative, supportive, and adequate teaching activities; teachers, educational groups, administrations, and learning-teaching communities have a role to play to get a full understanding of participants and a right impulse to optimize resources.

Ethics in education are embodied in professional ethics where education styles, models, and didactic methods are paramount. Teachers' conception and evaluation, together with the synthesis of main professional values used in their daily tasks and the ethical vision of education practice committed to equity and real fulfilment of people, provides for the full recognition of training actions and trainers. and evidences the real understanding of diverse cultures themselves and of their evolutions. This allows for the emergence of a fruitful significance of people and communities. Comprehension between people $[45,53,54]$ is to be supported by empathy and emotional harmony. The latter being the most relevant qualities shown for modalities such as relationships based on cooperation, comprehension, reciprocity, and shared experiences.

It is necessary to extend dialogue between cultures using a practical sense of wisdom and emotions triggering teachers' own feelings of otherness and enable sensibility towards others to generate a climate supported the teachers' intercultural learning [55]. New visions can emerge to answer challenges that are linked to sustainable human developments, and the commitments arising before pandemics or socio-economic crises. These evidence the axiological aspects that are at the very center of global and cultural concerns of human beings. Professional teams need be aware of this when getting implied in this new and complex society.

This is where the ethical competence is enriched by and actualized by principles like: Honesty, selflessness, responsible action, and human dignity; where open-minded and innovative professionals create a new style to act in full consciousness and assuming their authentic commitment and performance, when confronting the multiple challenges raised by new technologies, pandemics, and social and cultural uncertainties.

\subsection{The Methodological Dimension}

The above-mentioned competencies are reflected in professionals' personalities and axiology, while the methodological competence is linked to some adapted and justified norms that are discovered personally or jointly within the group to consolidate the communicative and empathic triggers with 
students. This enables the development of competencies and comprehension of knowledge that are to be assimilated [56]. The methodological competence summarizes the pertinent knowledge and actions shared by teachers and students to understand messages, apply them, and set up an integral training from a learning-teaching process. The vision of such a competence is concreted into the synthesis of pertinent knowledge, practices, values, and actions used to foment the comprehension of training contents, messages, etc. These are culturally relevant and are to be taught at school together with the attention to diversity and openness between people participating in the educational community [33].

The methodological competence helps teachers when building up a methodological system that is adapted to the needs of groups. It allows for improved individual and collective relationships and opens new understanding processes and comprehensions between communities like those observed in previously published works $[10,11,50,57-60]$, with diverse methods being reported.

Ref. [61] have summarized methods encouraging active education, project-based approaches, problem-solving procedures, and fractal education, with a particular attention to the application of the dialogical principle [10]. The latter is used as a basis and support for comprehension and understanding, and in provision with empathy between human beings. Intra and interpersonal relationships are deepened, and teachers and students' interactions are improved, with a marked importance for the diary every student must write during their learning experience to broaden the knowledge acquired.

The didactic methodology underlines the role and significance played by the cultural diversity and represents an integral methodological system that has to be set up by teachers and applied with originality in the group or using virtual means to answer the uncertain and complex situation experienced. We hereby present an integrated system based on (see Figure 1):

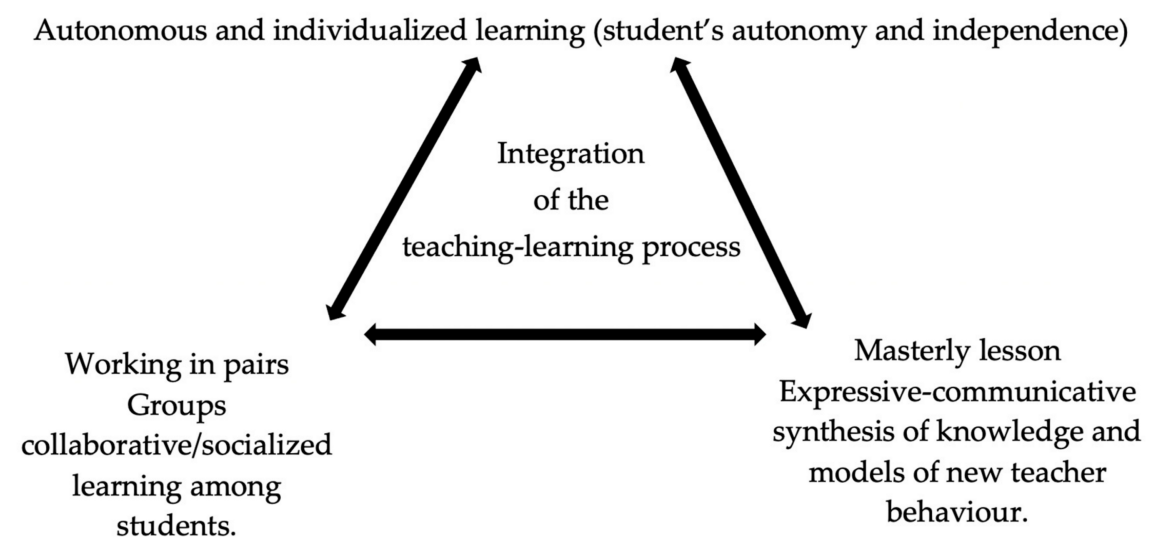

Figure 1. Integrated methodological system.

The setting up of a positive environment for improved understanding and relationships between cultures depends on the advances of the methodological system built by every group and teacher. All agents/students within the class-virtual group must become autonomous during their learning practice and become more committed with the work performed by it. The balance is gradually established between the theory and real practice/implication of teachers where dialogue, knowledge, and understanding between people and cultures are essential to respond to the equity and cooperation goals submitted by the 2030 UN agenda.

The educational practice meant to improve the understanding of cultures needs be enriched with a methodological system that provides renewed empathy for every participant within the group. Actions and decision-making procedures are to put human beings at the very center of educational institutions, where they can learn the key issues and limitations of localized entities. Then all work together inside the community to promote education from a global point of view, but considering the true needs expressed in specific contexts, to get a sustainable framework, balance, and cooperation between cultures. 
The integrated didactic-heuristic methodology $[60,62]$ is used to contribute to activities promoting a sustainable development using a case study [63]. This means it is used to provide a deeper and holistic knowledge of teaching-learning actions. Such an intercultural competence progress is linked to the build-up and application of methods oriented towards training practices and glocalized or complex principles like $[25,64,65]$. These integrate a new leadership vision of institutions that is projected into the actualization of initial and permanent teachers' training models. Teachers from early schooling to University stages learn to promote formative practices and concepts that are to be used in their daily lives and professions to foster new ways of providing intercultural dialogue and integral and mutual understanding.

\subsection{The Dialogue and Intercultural Understanding Dimension}

Getting trained in competences and, most particularly, getting trained in intercultural dialogue and understanding, means participants' acceptance and wide commitment to it. Teachers assume the consolidation of this professional competence sincerely, which is fundamental for the future of integral training regarding the understanding and shared education of people of diverse origins that are represented in the class. Ref. [62] advocates for a new implication of teachers and the application of a heuristic methodology that complements the didactic sense during the development of the teaching-learning process, at the very basis of the progress and achievement of the dialogue competence and intercultural understanding for the whole educational community within the physical, environmental, and sustainable environments.

The commitment dimension elevates the expectations of educational professionals and integrates in its methods a new way to consolidate practices fomenting a high level of understanding between participants within schools. Such a vision is consolidated when they finally understand the acceptation modalities of intercultural comprehension, and get pedagogical leaders to assume these challenges as necessary during their professional development, to provide for an innovative research line for all educational entities $[25,66,67]$, where managers and directors act as relevant innovators committed to the interculturality.

Progress made in the complementary educational competences like leadership, ecology, and new technologies [13,68-70]-linked to the sense of being and thought, to the professional identity, ethical dedication, and methodological competence-are to be promoted assuming the highest levels of commitment and the importance of research in this field, to provide for an integral education and comprehension of people of diverse cultural origins. Such competencies contribute to teachers' understanding and implication of the intense dialogue between participants, while accounting for the educational environment of schools as a whole and that of every group in their particularities.

Teachers' training is performed both at school and in ecological educational environments, where privileged settings impulse the sustainable development of schools themselves and that of societies. The 2030 Agenda objectives—most particularly those stated under the first paragraph — together with those detailing life and health goals, are meant to foment harmony, sustainability, equity, and comprehension between people during the educational process. Visions reported under [71,72] allow for a new model designed to impulse a constant ecological capital, used to collaborate with new cultures. This is meant to foster respect for ecological resources balance, use, and availability and help set a closeness between cultures' understanding our planet as a whole, where harmony, respect, and second-hand and integral care are part of our universal framework, with educational techniques being developed to face complex situations, glocalization, and systemization (holistic vision). 


\subsection{Research Question and Objectives}

\subsubsection{Research Question}

Is there a relationship between, on one hand, the development of professional identity, methodological and ethic competencies and, on the other, the advancement and improvement of the intercultural competence?

\subsubsection{General}

1. To identify the basis and competencies fostering teachers' empowerment on dialogue and understanding between human beings of different cultural origins. To build up a professional identity that is qualified to promote the integral development of society.

\subsubsection{Specific}

- To generate professional development models that are based on competencies.

- To discover the intercultural competence value for teachers and their commitment to it, together with its impact on integral development

- To demonstrate the projection that the advance in the competencies of professional identity, ethics, and methodological and professional commitment have in the construction of the intercultural understanding between people of different cultural origins for sustainable development.

- To transfer this intercultural competence progress to new professional and holistic development styles and models.

\section{Materials and Methods}

\subsection{Research Design}

The methodological design used in this research is mixed [73,74], allowing for both quantitative and qualitative data to be collected, analyzed, and linked altogether in the same study to answer research questions and objectives. This approach involves both the analysis of quantitative and qualitative data. It also supports multiple contrasts, category comparisons, and triangulation of results (complementarity of data, [75-79]). The intensely harmonized adaptation and style interpretation of texts-emerging from the focus group contributions and the open-ended answers to the questionnaires-are characteristic of the used for this type of research as observed by $[39,52,80]$.

\subsection{Sample and Context}

Sample is made of 100 participants corresponding to the relevant populations of our study: Experienced teachers, pertaining to the Secondary Education ( $40 \%$ of them) and to the Leon and Católica Santiago de Guayaquil (UCSG) Universities (35\%) and one part. Postgraduate Education Certification students, from the Universidad Nacional de Educación a Distancia (UNED) (25\%), also participated during their teaching and research training courses. About $38.0 \%$ of participants are aged 25 to 29 years; $35 \%$ are over 50 , and the other $25 \%$ are aged 30 to $49 ; 64 \%$ of participants are women, and $36 \%$ are men.

\subsection{Instruments and Data Collection}

The data were collected through a questionnaire and 3 focus groups. The questionnaire is made up of 47 items, gathered under four dimensions/components: Professional identity, ethics, professional commitment, and methodologic. Every dimension includes open-ended questions to allow for a further analysis of arguments given by participants. The Likert scale used includes a valuation of 1 (fully disagrees to) to 6 (fully agrees to). 
Questionnaire validation has been carried out by 15 experts, teachers, and researchers helping for the comprehension and transformation of data, the analysis of dimensions, and of their impact on every teacher. The reliability study was carried out using the SPSS. 22 system, evidencing a Cronbach's alpha of (0.972). The questionnaire was answered online by teachers participating, and focus groups were performed using the Zoom platform during the pandemic confinement.

The items developed by the focus groups were selected after reviewing the answers collected in open-ended questions of the questionnaire. The intention was to complement the responses obtained with those of focus group participating teachers, since these had sometimes been left aside in questionnaires. Other items were also included in focus group discussions by reviewing experts for their particular importance in one or the other dimension.

After a full written registry of focus groups and open-ended questions, an extended analysis of the contents of resulting accounts was performed, later completed by a triangulation study with experts' opinions. The Atlas ti 8.0 program was used to ease the presentation and categorization of findings. This all together enabled the emergence of new leads, verifying the coherence of data and the opening of relevant interpretations, that were also verified by researchers and teachers. Three focus groups with 8 participants each, representing the different knowledge areas and participant characteristics, helped to complement the perspectives and data obtained with the questionnaire.

\section{Results}

\subsection{Quantitative Analysis}

The factorial analysis applied is considering the correlative value between variables for every competence, associated to that of intercultural dialogue. The selection criteria are those reaching a correlation higher than $(>0.5)$, as follows:

First competence: Professional Identity, (we ignored 4, 5, and 9), Ethic-axiological (20, 24, 25), Professional Commitment (35), Methodology $(39,40,42,47)$ (corresponding to ad hoc data from the original questionnaire).

Values obtained for each variable identified by the corresponding competence are presented below (See Table 1).

Table 1. Results of the factorial analysis.

\begin{tabular}{|c|c|c|c|c|}
\hline & 1 & 2 & 3 & 4 \\
\hline \multicolumn{5}{|l|}{ Professional Identity } \\
\hline 1. Teachers need to get trained in migrant identities competencies. & 0.83 & & & \\
\hline $\begin{array}{l}\text { 2. Disagreements between people and cultures must be specifically worked on } \\
\text { during teachers' training. }\end{array}$ & 0.80 & & & \\
\hline $\begin{array}{l}\text { 3. The dialogic principle is to be worked upon by every teacher due to its high } \\
\text { impact on cultural improvement between cultures. }\end{array}$ & 0.79 & & & \\
\hline $\begin{array}{l}\text { 4. The diversity of cultures presents vast challenges for teachers to attend. } \\
\text { They must get trained in their knowledge and analysis. }\end{array}$ & 0.77 & & & \\
\hline $\begin{array}{l}\text { 5. The analysis of interactions between people from diverse cultural } \\
\text { backgrounds is essential for teachers' professional development. }\end{array}$ & 0.70 & & & \\
\hline \multicolumn{5}{|l|}{$\begin{array}{ll}\text { Ethic-axiological Dimension } \\
\end{array}$} \\
\hline $\begin{array}{l}\text { 6. Teachers need to get competences to understand the role played by the } \\
\text { intercultural dialogue in learning-teaching process. }\end{array}$ & & 0.78 & & \\
\hline $\begin{array}{l}\text { 7. Value analysis of the specific cultures represented in the group is key to } \\
\text { improve the teaching practice. }\end{array}$ & & 0.80 & & \\
\hline
\end{tabular}


Table 1. Cont.

\begin{tabular}{|c|c|c|c|c|}
\hline & 1 & 2 & 3 & 4 \\
\hline \multicolumn{5}{|l|}{ Ethic-axiological Dimension } \\
\hline $\begin{array}{l}\text { 8. Teachers' competencies in positive attitudes towards intercultural dialogue } \\
\text { at school is fundamental. }\end{array}$ & & 0.74 & & \\
\hline $\begin{array}{l}\text { 9. Teachers' training in reality-based account workshops to favor intercultural } \\
\text { understanding is fundamental. }\end{array}$ & & 0.78 & & \\
\hline $\begin{array}{l}\text { 10. Migrant issues knowledge is to be used as a basis for teachers' professional } \\
\text { development actions and models. }\end{array}$ & & 0.78 & & \\
\hline $\begin{array}{l}\text { 11. The generation of cultural understanding and cooperation with migrants' } \\
\text { identity/and expectations is basic to foment teachers' training models. }\end{array}$ & & 0.77 & & \\
\hline $\begin{array}{l}\text { 12. Migrants' values and lifestyles need be used to characterize teachers' } \\
\text { practice. }\end{array}$ & & 0.74 & & \\
\hline \multicolumn{5}{|l|}{ Professional Commitment Dimension } \\
\hline $\begin{array}{l}\text { 13. Teachers progress in their professional development when they prioritize } \\
\text { works based on intercultural dialogue. }\end{array}$ & & & 0.80 & \\
\hline $\begin{array}{l}\text { 14. Teachers appraise interculturality as a function used during the integral } \\
\text { education of students and families. }\end{array}$ & & & 0.76 & \\
\hline $\begin{array}{l}\text { 15. The learning-teaching process is to be adapted to the dialogue between } \\
\text { teachers and students. }\end{array}$ & & & 0.64 & \\
\hline $\begin{array}{l}\text { 16. Teachers have related their professional development with that of migrants } \\
\text { at school. }\end{array}$ & & & 0.70 & \\
\hline $\begin{array}{l}\text { 17. Teachers' experiences in the groups express their commitment and feelings } \\
\text { with migrant people. }\end{array}$ & & & 0.71 & \\
\hline $\begin{array}{l}\text { 18. Teachers widen their professional culture when fomenting an integral } \\
\text { education of people of diverse cultural backgrounds. }\end{array}$ & & & 0.91 & \\
\hline $\begin{array}{l}\text { 19. Families and migrants contribute to the professional development of } \\
\text { teachers. }\end{array}$ & & & 0.72 & \\
\hline \multicolumn{5}{|l|}{ Methodological Dimension } \\
\hline $\begin{array}{l}\text { 20. The ethnical and cultural dimension needs be included transversally in } \\
\text { education programs established by schools. }\end{array}$ & & & & 0.78 \\
\hline $\begin{array}{l}\text { 21. The attention to cultural diversity of students' needs be present at } \\
\text { fundamental stages of the learning-teaching process. }\end{array}$ & & & & 0.80 \\
\hline $\begin{array}{l}\text { 22. Teachers need to favor the active experience and exploration through } \\
\text { research works performed by the group. }\end{array}$ & & & & 0.63 \\
\hline $\begin{array}{l}\text { 23. Teachers need build up an integrated methodological system answering the } \\
\text { diverse expectations and cultures of students. }\end{array}$ & & & & 0.87 \\
\hline $\begin{array}{l}\text { 24. In multicultural contexts, teachers need to establish an educational } \\
\text { program that accounts for the significative cultural context of every student } \\
\text { (familiar and communicative means). }\end{array}$ & & & & 0.91 \\
\hline $\begin{array}{l}\text { 25. The promotion of dialogue between different cultures implies that teachers } \\
\text { need consider the social environment of groups: Values, beliefs, habits, } \\
\text { and expectations. }\end{array}$ & & & & 0.86 \\
\hline
\end{tabular}

When selecting the most valued variables (questions) among the four competencies (components), each of these values weighing over 0.70 were verified, except those corresponding to questions number 15 and 22, obtaining 0.64 and 0.63 , respectively. The most notable correlations corresponded to questions number 18 and 24, with 0.91 .

Factor analysis was enlarged using the Kaiser-Meyer-Olkin (KMO) statistics (Table 2), requiring of an inter-correlation of variables. The results collected present a value of 0.518 for $\mathrm{KMO}$, indicating the acceptation of the model. This analysis was further complemented with Bartlett's Sphericity test and reached a 0.815 , indicating that the proposed model of competencies is highly significant, with a Chi-square probability of 376 with $p<0.01$. 
Table 2. KMO (Kaiser-Meyer-Olkin) and Bartlett test.

\begin{tabular}{lcc}
\hline \multicolumn{2}{c}{ Medida Kaiser-Meyer-Olkin Sampling Adequacy } & 0.815 \\
\hline \multirow{3}{*}{ Bartlett's sphericity test } & Approx. Chi-square & 376.385 \\
\cline { 2 - 3 } & $\mathrm{gl}$ & 45 \\
\cline { 2 - 3 } & $\mathrm{Sig}$. & 0.000 \\
\hline
\end{tabular}

Variance is further examined and surveyed with a squared loading total of sums for rotations, presented in Table 3 (See Appendix A, Table A3).

Table 3. Total variance explained. Extraction method: Analysis of principal components.

\begin{tabular}{|c|c|c|c|c|c|c|c|c|c|}
\hline \multirow[b]{2}{*}{ Component } & \multicolumn{3}{|c|}{ Initial Self-Starting Values } & \multicolumn{3}{|c|}{$\begin{array}{l}\text { Extraction Sums of Squared } \\
\text { Loading Total }\end{array}$} & \multicolumn{3}{|c|}{$\begin{array}{l}\text { Rotation Sums of Squared } \\
\text { Loading Total }\end{array}$} \\
\hline & Total & $\begin{array}{c}\% \text { of } \\
\text { Variance }\end{array}$ & $\begin{array}{c}\% \\
\text { Cumulative }\end{array}$ & Total & $\begin{array}{c}\% \text { of } \\
\text { Variance }\end{array}$ & $\begin{array}{c}\% \\
\text { Cumulative }\end{array}$ & Total & $\begin{array}{c}\text { \% of } \\
\text { Variance }\end{array}$ & $\begin{array}{c}\% \\
\text { Cumulative }\end{array}$ \\
\hline 1 & 15.1 & 56.1 & 56.1 & 15.16 & 56.16 & 56.16 & 5.83 & 21.60 & 21.6 \\
\hline 2 & 3 & 11.1 & 67.2 & 3.00 & 11.13 & 67.29 & 5.26 & 19.51 & 41.1 \\
\hline 3 & 2.0 & 7.5 & 74.8 & 2.02 & 7.52 & 74.82 & 5.17 & 19.14 & 60.2 \\
\hline 4 & 1.2 & 4.4 & 79.3 & 1.21 & 4.48 & 79.3 & 5.14 & 19.04 & 79.30 \\
\hline
\end{tabular}

After feasibility of the factorial analysis determination, we proceeded to find the explained variance, and observed that for the four components/dimensions, the variance established a 79.30 of data information. The first component-the Professional Identity competence-accounted for $21.6 \%$ of data. The second component-the Ethics-accounted for 19.51\%, the Professional Commitment for $19.14 \%$, and the Methodological for $19.04 \%$.

Such weights represent a high level of total variance explained. The Professional Identity stands out, though for the other competencies, the level of explained variance is like the latter with a $19.5 \%$. The model of competencies reviewed by participants presents a high relation with the analyzed competence (dialogue between cultures-intercultural), showing the existence of a close and complementary connection and adequate competence framework to train teachers.

\subsection{Qualitative Analysis}

Methods: For the focus groups and open-ended questions, content analysis based on grounded theory was applied, allowing us to identify the main codes and an additional categorization of data using the inference $[81,82]$. In the first place, researchers read the written material several times, acquiring a deep level of familiarity with it. Then, they worked independently, dividing the text into smaller sentences and assigning a specific code to each of them. In a following phase, researchers revised and discussed individual interpretations, verifying whether the identified codes were the same. Researchers compared their results and eliminated possible redundancies. Similar codes were discussed and clustered to reduce the codes to as small a number as possible. Data were then related, and all participants' accounts were batched to interpret the collected data. Later, relations between codes were identified, and a number of categories, which included the individual codes, emerged from the analysis. At the end of the discussion, all the members of the research team had a shared understanding of the codes and categories, and the confirmed codes were organized in semantic networks. Findings for each dimension with the main quotations are presented hereafter under separate sections.

\subsubsection{Professional Identity}

- $\quad$ Item 1.1. 
1. Personal and professional self-knowledge are fundamental aspects to comprehend other people's way of thinking (see Figure 2):

"The improved professional identity probably had been made possible after personal experiencing. These experiences of coexistence and treatment with people of diverse cultures, have allowed for a broader understanding of other people's identities and cultures".

2. Teachers need to define more clearly their functions when confronted to culturally diverse contexts and that the professional identity of teachers is linked to their vocation:

"Any teacher with a clear educating professional identity will understand better and will be more willing to adapt to the presence of other cultures inside the class'. (... ) 'I know from my own experience that, even teachers expressing their non-implication in the educating process and their concentration on the instruction role, finally end up analysing concrete situations and are finally compelled to understand and consider the (cultural, social, family, etc.... ) circumstances of students they work with".

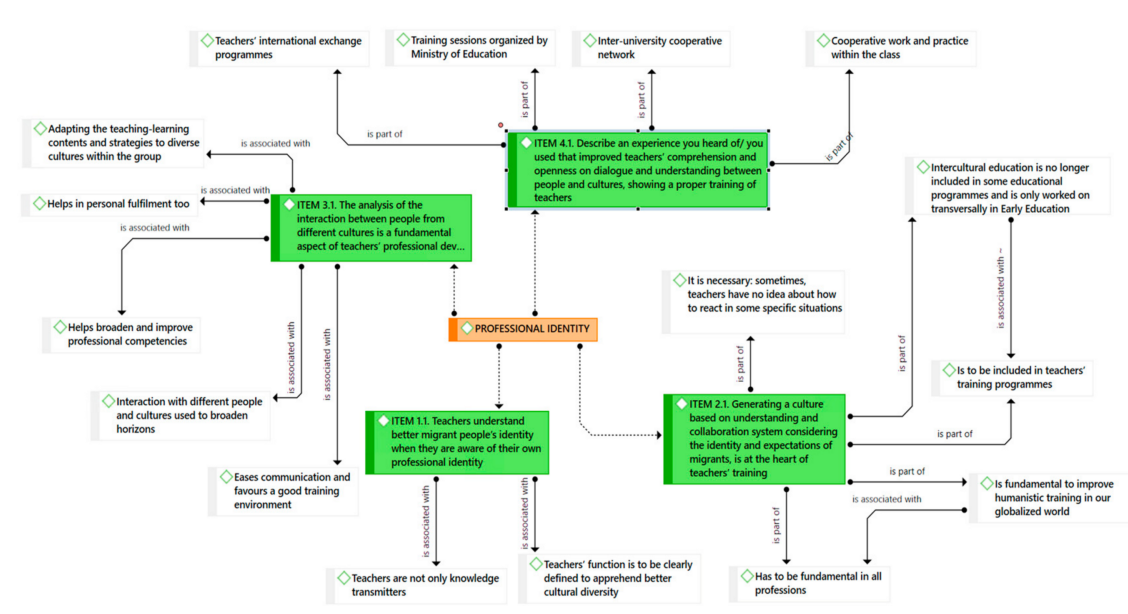

Figure 2. Semantic network of the Professional identity dimension.

- $\quad$ Item 2.1.

1. Participants express that such an aspect needs be included in training programs for teachers. Some say that:

"Some basic notions prove fundamental for teachers" training'; others that "I think this should be necessarily included in teachers' training". They assume that such a necessity comes from "the fact that sometimes you just don't know to react before particular situations or students' attitudes of different cultural backgrounds due to the diversity of habits and behaviours".

2. The intercultural education has disappeared in some educational programs or are only treated transversally in Early Education classes:

"I find it is fundamental. In the ULE (University of León, Spain), we had an Intercultural Education subject, but it is no longer offered. What a pity'. "During the Education Certification, I think I only had a few hints in one or two subjects (though no specific subject was provided on that". 
All participants consider the understanding and identity cooperation with people of diverse origins to be fundamental in all professions, as "it is essential to improve humanistic training in our globalized world".

- $\quad$ Item 3.1.

1. Interacting with people of different cultures derived into some personal enrichment and development:

"The presence within the group of diverse cultures was felt positively because it accounted for both teachers and students' development". "Whenever a cultural exchange is provided, personal development occurs. The presence of people of diverse origins is directly linked to personal growth and to professional development too".

For students and teachers implied in the present research, the analysis of such an interaction "favours communication and provides a positive training environment".

- $\quad$ Item 4.1.

1. Cooperative work and practice within the class:

"A student of Muslim origin had difficulties to express (when he started with us). He had a different culture, a different way to relate with people. We designed activities to promote relationships with his fellows and, at the end of the semester, he managed to become completely independent. He did not need help from the teacher anymore since his classmates helped spontaneously to overcome obstacles".

2. Teachers' International Exchange Programs (see Figure 2):

“In Brazil, the Academic International Program for Scientific Mobility (PCSF): All students found interesting to adapt some activities included in the subject and provide for an improved acquisition of competences because it presented a training interest for foreign students and could be adapted to their countries of origin. This actually contributed to the cultural and training enrichment of both groups". "A cooperation between teachers from the Universidad de León, Spain (ULE) and the Xiangtan University, China, was set up to train Chinese students both in Spain and in their country of origin by teachers moved from the ULE to train them".

3. Experiences where teachers have adapted the ethic-axiological contents and strategies to meet the needs of students of different cultures within the group:

"We organised sequenced remote work during a whole year for a gypsy student living with seasonal working parents. We knew from the start, the lecturing periods he could attend school, and planned the rest to do remote sessions".

Finally, some Secondary Education teachers express they participated in training courses on intercultural education organized by the Spanish Ministry of Education.

\subsubsection{Ethics}

- $\quad$ Item 1.2.

1. Teachers need to always find some emotional connection with people participating in the educational community. Empathy improves comprehension and the resolution of complex situations (see Figure 3): 
"I believe that teachers need to find some emotional connection and feel empathy is a personal tool they can use in their daily work". "In my opinion, teachers need get oriented towards empathy and emotional cooperation, to attend all students without bias. Personal and individual contexts sometimes require more attention than other socio-cultural ones".

2. Education must be personal formative project, where all actors need be reflected, and they express it as follows:

"Activity within the class is a social activity that implies empathy and emotional connection with people with the same or different culture, religion ... ; this is why teachers' training needs fundamentally to include personal resources allowing for some emotional connection between people sharing the same professional activity".

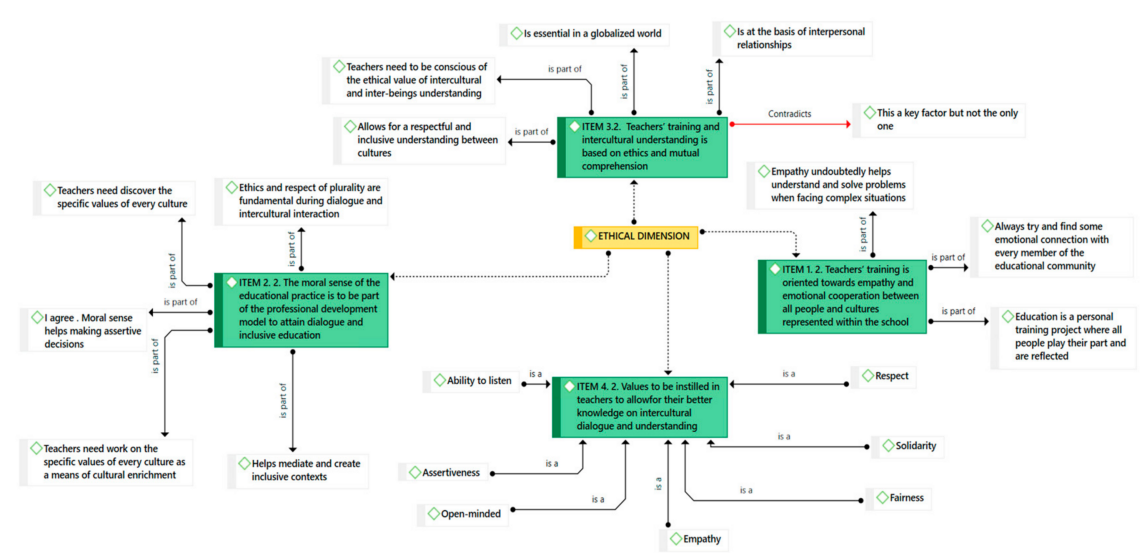

Figure 3. Semantic network of the Ethical dimension.

- $\quad$ Item 2.2.

1. It foments teachers' competence to be a mediator and generate inclusion contexts (see Figure 3):

"Whatever the subject, teachers must assume their conciliating role to promote respect towards other cultures (including the less represented ones within the group) to attain a full integration and participation of students".

2. Teachers need to discover/get to know the specific values of every culture to use them as an enrichment tool:

"I cannot improve my own professional development if I do not try and discover the different cultures and their specific values. I need to indagate their substantial value and their importance in every culture". "I agree with this, because teaching includes a very important moral aspect where the interculturality and inclusion of students are basic, whatever their cultural background".

3. The ethical sense and the respect of plurality as fundamental for dialogue and intercultural interaction:

"It is necessary and unavoidable during the learning and teaching process to educate good students and to educate responsible adults that are to participate in society. This includes getting some ethical values."

4. The moral sense of educational practices truly helps taking decisions in an assertive way. Participants express that: 
"Many decisions taken within the class bear some ethical or moral characteristics, though we sometimes are unaware of this". "Teachers will always need during his teaching practice to take ethical and moral decisions that are linked to the education in values area. Teachers because they are adapting aspects of the programme or tutors because they are confronted to specific actions to make".

- $\quad$ Item 3.2.

1. The ethical sense and cultural understanding between cultures are essentials in our globalized world, because it allows for a more respectful and integrated comprehension between cultures, as a basis for interpersonal relationships (see Figure 3):

"Yes, this is essential. It is part of our education in values. Our own education. And this is something that can easily help create a favourable environment inside the class. It also provides for multiple perspectives that, occasionally, are necessary due to the reductive -or occidental-character we tend to apply to our investigations and our professional practice."

2. The ethical sense and the comprehension between people are not sole factors and has to be considered as a basis for teachers' training:

"As commented before, I don't believe that the improvement of intercultural relationships is to be "pushed" as compulsory basic within teachers' curriculum. Such a training transcends the teaching profession and has to be considered as a preparation for social individuals."

3. Teachers need be aware of the ethical value of such a cultural understanding considering that:

"In many cases, teachers act mistakenly with students of diverse origins, because they have no idea about how to proceed. If we had a sound training in these aspects, I believe, everything could go smoothly, and we would face less problems in the class."

This statement coincides with answers given to questions included in other dimensions and affirms the need for an inclusion of these aspects of dialogue and intercultural understanding in the initial and permanent training of teachers.

\section{- $\quad$ Item 4.2.}

1. All participants agreed that the main value to be fostered is empathy (see Figure 3):

"To be able to identify others as equals: an image in my mirror". "Putting yourself in someone else's shoes and understand how they feel and are confronted to cultural shocks is basic for integration".

2. It is equally important and fundamental to foment the progress and understanding between cultures fostering equity, ability to listen, open-minded capacity to learn the way people of different origins feel and think, and solidarity and respect:

"We need understand different cultures, habits, thoughts, beliefs and lifestyles". "We need to learn and respect the values linked to other cultures though to do so we need to get to know them, this is our first task to perform".

"The best and most important opening up is when I become aware of how I learn and improve. This is when I start to appreciate diversity". 


\subsubsection{Professional Commitment}

- $\quad$ Item 1.3

1. Reflection of the commitment level of the educational institutions to foment permanent training of teachers is underlined. Some students considered that (see Figure 4):

"The level of commitment inside the institutions was actually far from reaching an open dialogue and close understanding with each culture. The institutions must be conscious of their educational discourse and programs".

2. Microcultures (groups) represented in the educational centers are usually slowing down some initiatives:

"There are cultures restraining or speeding up such process, so we need the directors to change the internal organization of schools".

3. Schools need to be based on inclusion and respect towards all, and mostly with different cultural identities:

"This must be a common work undertaken by directors, the administration, families, teachers, and students themselves".

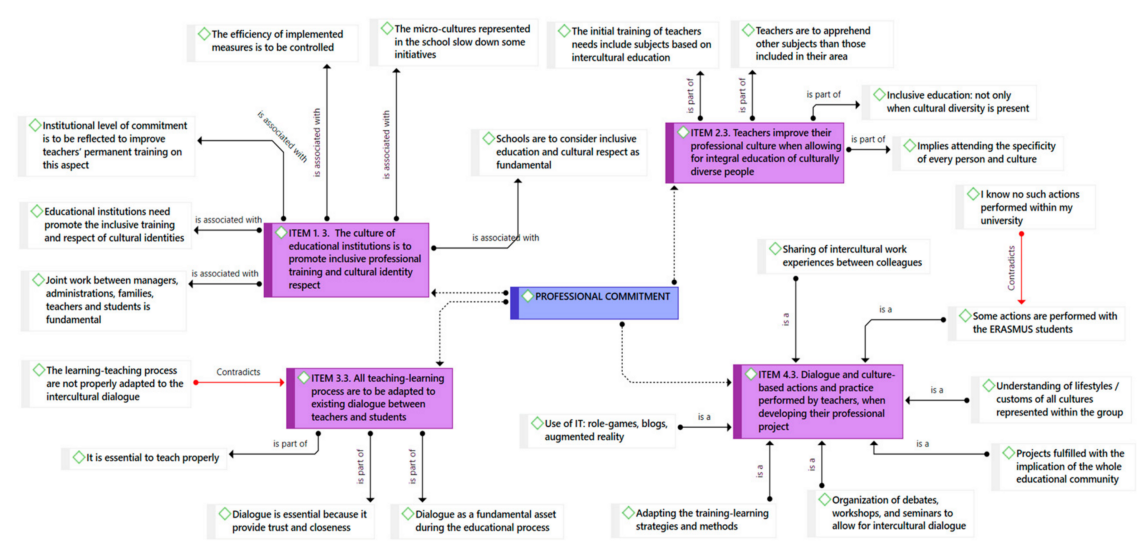

Figure 4. Semantic network of professional commitment.

Participants underlined the importance of verifying the efficiency of all measures set up in schools to promote respect and the diversity of cultural identities.

- Item 2.3. Participants expressed the following ideas to answer this item (see Figure 4):

1. They believe that it also implies attending the specificity of every culture since:

"It enlarges the professional culture of teachers and provides some added value to his/her personal and professional competencies. Teachers try to understand and integrate people with different cultures, languages, religions, etc ... this demands some personal and professional adaptations".

2. Some intercultural education subjects need to be included in the initial training of teachers (this aspect has been underlined in the previous dimension too). They also point out that teachers must cross the frontiers of their own subjects to teach:

"I agree, because the environment within the class is improved when classes go smoothly"; "no doubt about that, working with persons of diverse origins enhances the enrichment of their professional culture". 
- $\quad$ Item 3.3.

1. The learning-teaching process need be adapted to the dialogue between teachers and students (see Figure 4):

"Dialogue is fundamental because it generates proximity and confidence; it is unavoidable to teach in a correct way and it provides a basis for the educational success".

2. Participants also consider that the teaching-learning process in many cases do not adjust to the dialogue between different cultures represented inside the class.

- $\quad$ Item 4.3.

1. Participants consider as essential the expertise in other languages, lifestyles, and cultural habits, the development of projects where the whole educational community is implied, the use of IT, the shared experiences between teachers and, most of all, the inclusion of ERASMUS students in universities (see Figure 4):

"We used a flipped classroom methodology where three Erasmus students from Argelia, presented orally the cattle-raising industry of their region and explained its cultural importance. They explained the essential role played by the halal rules (animal throat cut in a single swipe to drain blood out of the carcass before it is allowed for food) as the sole lawful practice before human consumption".

"The "Viva la diferencia" Project was carried out with teachers and students of Secondary Education and Primary Education centres. Performed with the help of the ACCEM Association (NGO). The objectives of the project versed on interculturality, global diversity-stereotypes, languages, habits, prejudice ... ".

2. Some university students expressed that they had never had any experience of such practices and had not heard of one either:

"I don't know any program attending specific training in these fields at university. I heard of some developed by teachers in lower grades (primary and secondary education) like conferences or chats on the gipsies".

3.2.4. Methodological

- $\quad$ Item 1.4.

1. Cultures presenting some specificities that are to be considered when preparing the methodological approach of subjects (see Figure 5):

"The introduction of contents related to diverse cultures means avoiding subjects that can be quite upsetting or designing activities where students of different origins play a role".

2. Teachers must consider all students' expectations inside the group:

"Teachers understand that, from a methodological point of view, all students are different so, why not considering the existing cultural diversities in the same class?".

3. A quality-based education must be adapted to students' needs:

"That a methodological system considering the cultural diversity in the group is an added value for all. Because, the final aim is to raise society and individuals, personally and professionally". 
4. This methodological system needs be worked upon transversally by the whole school:

"The understanding and dialogue between all cultures is a resource that needs be worked on. Because there are more unifying aspects than differentiating ones. People of diverse cultural origins can live together and, this is where a methodological system plays its part while integrating diversity in the whole educational practice".

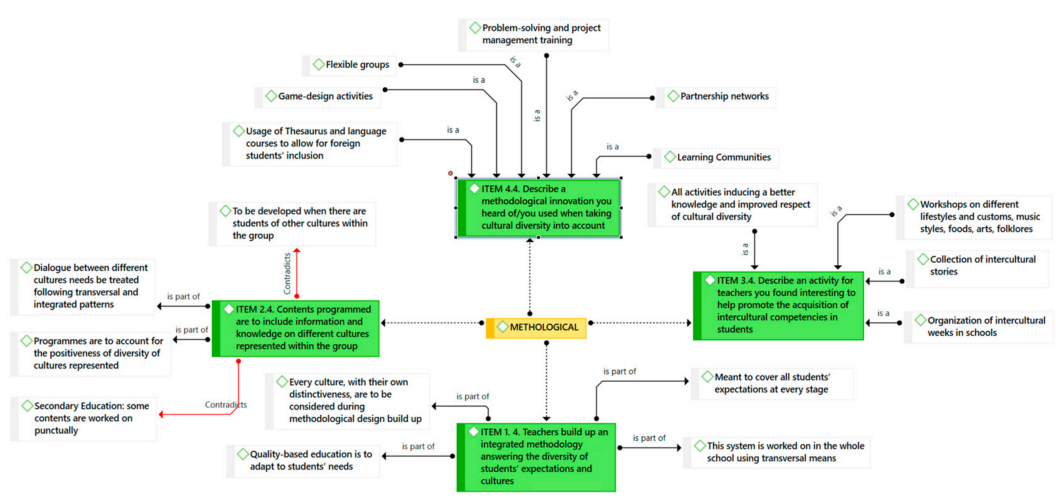

Figure 5. Semantic network of the methodological dimension.

- $\quad$ Item 2.4 .

1. Educational planning need include contents referring to the diversity of cultures, and that (see Figure 5):

"There are actually some contents on these subjects, but they are only worked on punctually and only linked to some particular areas".

2. Knowledge on cultural diversity is only examined when such a diversity is present in the group:

"Whether there are or not students of different cultures, the inclusion of such contents in the planning is essential".

- Items 3.4, 4.4. These items are analyzed jointly due to the similarity of answers given by participants (see Figure 5):

1. Use of a Thesaurus and of a linguistic adaptation to ease students' inclusion. However, one participant considered such adaptations as:

"Non adequate in primary education and early education and restrain students' attention. The attention of these students could be partially taken care of inside the school by specialised teams".

2. Use of active methodologies:

“Like problem-solving or project-based techniques, role-playing, flexible focus groups, networks and learning communities".

3. Other important activities for them are:

"The workshops, intercultural weeks with the whole community participating, families, students, teachers and, in general, all persons fomenting the knowledge and respect of diverse cultures". 


\subsection{Complementarity of Quantitative and Qualitative Data}

After performing a qualitative and quantitative analysis of data, we conducted a complementarity of data, obtained for each dimension. The following table (Table 4) presents a synthesis for each competence. Total data on complementarity can be obtained from Tables A2-A5 in Appendix B.

Table 4. Complementarity of data.

\begin{tabular}{|c|c|c|}
\hline Competencies & $\begin{array}{c}\text { Qualitative Analysis (Focus } \\
\text { Groups/Open-Ended Questions Results) }\end{array}$ & $\begin{array}{l}\text { Quantitative Analysis } \\
\text { (Questionnaire Results) }\end{array}$ \\
\hline $\begin{array}{l}\text { Professional } \\
\text { Identity }\end{array}$ & $\begin{array}{l}\text { - When professional identity is consolidated, } \\
\text { the personal and professional self-concept are } \\
\text { improved, too. Teachers cannot be solely a } \\
\text { transmitter of knowledge. } \\
\text { - The teachers' function is to be clearly defined to } \\
\text { confront cultural diversity contexts and } \\
\text { apprehend his/her vocation positively. Every } \\
\text { teacher must understand and consider the } \\
\text { (cultural, social, and family) circumstances of } \\
\text { students. } \\
\text { - The basis for educational innovative models is to } \\
\text { be the empowerment of teachers to understand } \\
\text { and consider other cultures. }\end{array}$ & $\begin{array}{l}\text { - The needs for teachers' competence in migrant } \\
\text { identity is confirmed. The average obtained is } \\
5.15 \text {. } \\
\text { - The analysis of interaction between people of } \\
\text { diverse cultures is fundamental for teachers to } \\
\text { develop professionally }(0.70) \text { factor weight. } \\
\text { The average obtained is } 5.09 \text {. } \\
\text { - Cultural diversity presents vast challenges and } \\
\text { teachers need to get the necessary knowledge } \\
\text { and analytic competencies on this }(0.77) \text {. } \\
\text { The average obtained is } 5.27\end{array}$ \\
\hline Ethical & $\begin{array}{l}\text { - Teachers need to develop an emotional } \\
\text { connection with all people participating in the } \\
\text { educational community and institutions. } \\
\text { - Teachers must learn how to mediate and } \\
\text { generate contexts allowing for inclusion. } \\
\text { - Equity, ability to listen, openness, cultural } \\
\text { solidarity, and respect are essential values to } \\
\text { foment dialogue and intercultural understanding. }\end{array}$ & $\begin{array}{l}\text { - Teachers must be trained to understand the } \\
\text { sense of dialogue between cultures during the } \\
\text { teaching-learning process. The value obtained } \\
\text { for this is factor is } 0.78 \text {, and the average is of } \\
4.91 \text {. } \\
\text { - Knowledge on migrants' issues is to be at the } \\
\text { very base of models and actions for improved } \\
\text { professional developments. The value obtained } \\
\text { is of } 0.78 \text {, for the corresponding factor. } \\
\text { - Generating a culture that is based on } \\
\text { understanding, identity cooperation, } \\
\text { and migrants' expectations. Weight obtained } \\
\text { for the factor is } 0.77 \text {. The average obtained is } \\
4.48 \text {. }\end{array}$ \\
\hline $\begin{array}{l}\text { Professional } \\
\text { Commitment }\end{array}$ & $\begin{array}{l}\text { - Participants express the level of commitment of } \\
\text { Institutions is adequate to improve teachers' } \\
\text { training, though some feel differently. } \\
\text { - Joint work must be performed between directors, } \\
\text { administrations, families, teachers, and students. } \\
\text { - The teaching-learning process must adapt to the } \\
\text { dialogue between students and teachers. }\end{array}$ & $\begin{array}{l}\text { - The culture of institutions must promote the } \\
\text { inclusion and respect of migrant identities. } \\
\text { Weight for this factor is lower than } 0.64 \text {, though } \\
\text { its average is one of the highest registered (5.33). } \\
\text { Teachers consider interculturality as an integral } \\
\text { educational function for families and students. } \\
\text { Weight for the factor is of } 0.76 \text {. Average of } 4.82 \text {. } \\
\text { - The teaching-learning process must adapt } \\
\text { dialogue between teachers and students. } \\
\text { Weight for this factor is } 0.64 \text { and average } 5.31 \\
\text { (one of the highest for this competence). }\end{array}$ \\
\hline Methodological & $\begin{array}{l}\text { - Cultures show some specificities that need be } \\
\text { attended from a methodological design point of } \\
\text { view. } \\
\text { - The development of a methodological system, } \\
\text { that is performed transversally and is assumed by } \\
\text { the whole educational community. } \\
\text { - Planning need to integrate contents on cultural } \\
\text { diversity knowledge. "The inclusion of contents } \\
\text { based on cultural diversity knowledge is } \\
\text { productive because it provides teachers with } \\
\text { other tools." }\end{array}$ & $\begin{array}{l}\text { - The ethical and cultural dimension must be } \\
\text { included in the transversal way planning and } \\
\text { educational agendas are established by schools. } \\
\text { The value obtained after factorial analysis } \\
\text { performed is of } 0.78 \text {. The average is } 5.09 \text {. } \\
\text { - Teachers must build an integrated } \\
\text { methodological system that answers the } \\
\text { students' diversity of expectations and cultural } \\
\text { issues. Factor weight: } 0.87 \text {, one of the highest } \\
\text { for this component. The average is } 5.30 \text {. } \\
\text { - When facing multicultural contexts, teachers } \\
\text { need to set up an educational design that } \\
\text { considers students' significant cultural contexts. } \\
\text { Factorial analysis evidences a value of } 0.91 \text {, } \\
\text { the highest value observed for variables of this } \\
\text { factor. Average: } 5.38 \text {. }\end{array}$ \\
\hline
\end{tabular}

The information gathered confirmed the high rating obtained by the presented competencies in the answers given by many educational and intercultural environments experts. 
Findings on the Professional Identity competence assessment evidence that it comes top of the list with most values reaching 5 points on a maximum scale of 6; some reaching 5.39 like those corresponding to the 'dialogical principle'. This competence is considered of high impact to promote adequate relationships between people and cultures; the competence reaches $21.6 \%$ in terms of total variance explained.

The other competencies get similar percentages with $19.5 \%$ and $19.04 \%$. The answers gathered and the explicit analysis of focus groups and interviews underline that the educational practice demands a wide knowledge of people, communities, culture, and group plurality when teaching. Participants express that teachers are often confronted to contexts where cultural diversity is present. They are supposed to make decisions that are coherent with the improvement of professional identity and the use of raised ethical competencies. They are also expected to have a high knowledge of practical methods fomenting dialogue, accounts, case studies, and problem-solving learning. They are supposed to generate methodological systems that are integrated into and adapted to cultural plurality, while being empathic with the demands issued by different communities and intercultural environments.

\section{Discussion and Conclusions}

The theoretic substantiation presented in this article highlights the impact of the investigation process in consciousness-raising regarding knowledge-building. This is particularly important when practical experiences are performed through reflexive activities and inquiries, based on a qualitative approach, as showed by [78]. Research analysis on the intercultural competence of teachers' training underlines that specific empowerment is fundamental to promote the integral development and the transformative understanding between people, communities, and diverse cultures, as stated by the works of $[18,29,50,69,83-85]$. Its effects are altogether more intense and its outreach greater when the improvement of this competence is linked to that of the professional identity competence $[32,35,36,39,86]$.

The vision of $[42,87,88]$, confirms the findings of the present research on the building process of competencies, with a singularly higher significance for the Professional Identity one. Results underline that such a competence improves when teachers and students are implied in the performance of permanent investigations and update process. The educational practice become then an inquiry methodology where every teacher finds ways to improve professionally and integrally.

Participants considered such competence as a basis and complement to foment interculturality, coinciding with results of other research [41,43,44]. Previous findings by [33] (p. 4) have confirmed that: "The selection of most formative experiences by every teacher is part of the professional reflection and development process". This was evidenced in focus groups and interviews too. Finally, a coincidence of results with [37] is also observed as to the socialization process provided by teachers' trainers and its impact on future educational professionals, which is highly valued and considered by teachers.

The ethic-axiological competence included here focuses markedly on the need for teachers to assume new challenges and recover values like: Equity, justice, non-discrimination, and overcoming stereotypes, as cited in the previous works of $[38,47,53,59]$. Such a challenge implies an intense ethical commitment with cultural diversity, supported by new values enhancing dialogue and renewing the dialogical principle in coherence with suggestions made by [10]. The integral commitment competence has amplified an open vision and complicity towards the eco-training and sustainable ecology. High ratings are obtained by the corresponding factor in coherence with previous works and visions $[51,65,71,72]$. These altogether underline the essential significance of respect and understanding on cultural diversity and environmental-ecological issues and values, generated by diverse cultures [48].

Complementarity between the studied competencies is consolidated with the analysis findings of the Methodological one. They show the adequacy and need for teachers and students' training sessions on innovative empowerment methods to be performed to foster understanding and dialogue between people of different cultural origins. Strategies used can be based on active or collaborative-creative Methodologies and transformative actions impacting on ecosystems and integral developments, 
as stated in $[14,18,60,68,70,89]$. These authors concur in the importance of generating and using holistically integrated methods to strengthen teachers' training and broaden horizons to improve intercultural education and sustainable development.

Our conclusions meet those marked by the essential objectives of the ComProfesu and the Universidad Católica de Santiago de Guayaquil-UCSG (Ecuador) projects. These entities have issued teachers' training models that are based on dialogue, cultural understanding, and didactic harmony between teachers in High Schools and Universities.

The objectives and the research question marked by the present study were reached with the generation of professional development models based on competencies and the evidence of the added value provided by the dialogue and the intercultural understanding competence. High values were obtained for these in most questions-with a total of five and six points, in a 1 to 6 points scale-Showing a wide acceptation of the professional development model offered from competencies, most particularly those concerning the identity and professional commitment.

The explained variance (79.3) obtained for the four selected competencies and their contribution to the progress and consolidation of 'intercultural dialogue and understanding', confirms the needs for models to be designed to enhance teachers' professional development and integral qualification in competencies. The intercultural competence is considered as a priority in our modern and complex world.

A group of methods, tasks, didactic interactions events, and integral development networks (RIAICES, 2020) has been set up to account for the dialogic principle and intercultural understanding work and evaluation of participants. These are reflected in didactic interaction perspectives newly developed by groups, communities, and settings open to complexity $[3,6,38,47,59,90,91]$. These tools represent intelligent contexts and new environments, where the eco-training, cultural dialogue, and sustainable ecology are concretely developed in total emotional harmony and with true empathy [24].

Author Contributions: Conceptualization, A.M.R., M.C.D.G., M.C.M.D., A.R.-C., and E.P.N. methodology, A.M.R., M.C.M.D., A.R.-C., and M.C.D.G.; software, A.R.-C., E.P.N., M.C.L.D., and A.M.R; validation, M.C.D.G., M.C.M.D., A.R.-C., and M.C.L.D.; formal analysis, A.R.-C., E.P.N., and A.M.R.; investigation, M.C.L.D., A.R.-C., M.C.D.G., M.C.M.D., E.P.N., and A.M.R.; writing-original draft preparation, A.M.R., A.R.-C., E.P.N.; writing-review and editing, M.C.M.D., M.C.D.G., and A.R.-C.; funding acquisition, M.C.D.G., M.C.M.D., and A.M.R. All authors have read and agreed to the published version of the manuscript.

Funding: This research was funded by The Spanish Ministry of Economy and Competitiveness Code EDU2016-78451-P and the Research Project Code SINDE 464-451-UNED-UCSG. The APC was funded by Universidad Nacional de Educación a Distancia-UNED.

Acknowledgments: The authors would like to thank the teachers and students for their cooperation in this study.

Conflicts of Interest: The authors declare no conflict of interest. The funders had no role in the design of the study; in the collection, analysis, or interpretation of data; in the writing of the manuscript, or in the decision to publish the results.

\section{Appendix A}

Table A1. Total variance explained.

\begin{tabular}{llll}
\hline 5 & 0.96 & 3.5 & 82.8 \\
\hline 6 & 0.87 & 3.2 & 86.1 \\
\hline 7 & 0.72 & 2.6 & 88.8 \\
\hline 8 & 0.55 & 2.0 & 90.8 \\
\hline
\end{tabular}


Table A1. Cont.

\begin{tabular}{|c|c|c|c|}
\hline 9 & 0.51 & 1.9 & 92.81 \\
\hline 10 & 0.42 & 1.5 & 94.36 \\
\hline 10 & 0.42 & 1.5 & 94.36 \\
\hline 11 & 0.37 & 1.3 & 95.74 \\
\hline 12 & 0.25 & 0.95 & 96.69 \\
\hline 13 & 0.21 & 0.78 & 97.47 \\
\hline 14 & 0.16 & 0.60 & 98.07 \\
\hline 15 & 0.14 & 0.54 & 98.62 \\
\hline 16 & 0.12 & 0.45 & 99.07 \\
\hline 17 & 0.08 & 0.30 & 99.37 \\
\hline 18 & 0.05 & 0.20 & 99.58 \\
\hline 19 & 0.04 & 0.15 & 99.73 \\
\hline 20 & 0.02 & 0.10 & 99.84 \\
\hline 21 & 0.02 & 0.08 & 99.92 \\
\hline 22 & 0.01 & 0.04 & 99.96 \\
\hline 23 & 0.006 & 0.02 & 99.99 \\
\hline 24 & 0.002 & 0.008 & 99.99 \\
\hline 25 & 0.000 & 0.002 & 100.00 \\
\hline 26 & 0.00 & 0.000 & 100.00 \\
\hline 27 & $-1.252 \times 10^{-16}$ & $-4.636 \times 10^{-16}$ & 100.00 \\
\hline
\end{tabular}

Extraction method: Analysis of principal components.

\section{Appendix B}

Table A2. Complementarity of data: Professional Identity Dimension.

\begin{tabular}{|c|c|c|}
\hline & Qualitative Analysis (Results, Interviews, Focus Groups) & $\begin{array}{l}\text { Quantitative Analysis } \\
\text { (Questionnaire Results) }\end{array}$ \\
\hline PROFESSIONAL IDENTITY & $\begin{array}{l}\text {-Teachers must get specific training on dialogue with other } \\
\text { cultures. "Some Universities do not include anymore this } \\
\text { dimension in their educational planning (intercultural } \\
\text { dialogue, professional identity)". They underline the necessity } \\
\text { for some humanistic competence to improve Identity since the } \\
\text { interaction with other cultures is the basis for personal } \\
\text { development. "With cultural exchange, people are enriched". } \\
\text { - Collaborative work inside the group is improving } \\
\text { professional identity and eases understanding with other } \\
\text { cultures. "The promotion of relationships between students of } \\
\text { diverse cultural origins enhances students' independence". } \\
\text { - University Exchanges (ERASMUS program) have helped } \\
\text { foment dialogue and professional/personal identities within } \\
\text { universities. } \\
\text { "The Exchange of experiences at university has improved the } \\
\text { identity and increased the reciprocity". "Teachers adapt } \\
\text { contents and teaching-learning strategies to cultural diversity". } \\
\text { "During the Ramadan, we adapt the works and exams". } \\
\text { "Sometimes, teachers escort mistakenly students of other } \\
\text { cultures due to their lack of". }\end{array}$ & $\begin{array}{l}\text {-The dialogical principle needs } \\
\text { be worked on by every teacher, } \\
\text { due to its impact on the } \\
\text { improvement of relationships } \\
\text { with other cultures } \\
\text { (0.79) The direct average } \\
\text { obtained is of } 5.39 \\
\text { The understanding between } \\
\text { people of diverse cultural origins } \\
\text { needs be worked on by teachers } \\
\text { and be considered as a priority } \\
\text { objective, }(0.83) \text { factor weight } \\
\text { and average of } 5.09 \text {. } \\
\text { - Teachers' training in the social } \\
\text { relationships comprehension } \\
\text { with diverse cultures is essential. } \\
\text { Weight for factor is } 0.80 \text {. Average } \\
\text { obtained } 5.39 \text {. }\end{array}$ \\
\hline
\end{tabular}


Table A3. Complementarity of data: Ethical Dimension.

\begin{tabular}{lll}
\hline & \multicolumn{1}{c}{ Qualitative Analysis } & \multicolumn{1}{c}{ Quantitative Analysis } \\
\cline { 2 - 3 } & $\begin{array}{l}\text { Education is embodied in a personal training project } \\
\text { where all participants must play their part. } \\
\text { "We need to make sure they learn how to use personal } \\
\text { resources to connect emotionally with others". }\end{array}$ & $\begin{array}{l}\text { Teachers' training in dialogue between diverse } \\
\text { cultures at school. } \\
\text { Result obtained with factor analysis is 0.74. } \\
\text { The average obtained is 5.03. }\end{array}$ \\
\cline { 2 - 3 } & $\begin{array}{l}\text { The most valued aspect to foment dialogue and } \\
\text { intercultural understanding is that of empathy. } \\
\text { "It is basic for the integration of people to be able to put } \\
\text { oneself in the others' shoes and try to understand how } \\
\text { they feel". }\end{array}$ & $\begin{array}{l}\text { Values and lifestyles of migrant people need be } \\
\text { represented and considered during school } \\
\text { activities. The result obtained is of 0.74. } \\
\text { The average obtained is 4.48. }\end{array}$ \\
& & \\
\hline
\end{tabular}

Table A4. Complementarity of data: Professional Commitment Dimension.

\begin{tabular}{|c|c|c|}
\hline & Qualitative Analysis & Quantitative Analysis \\
\hline \multirow[b]{2}{*}{$\begin{array}{l}\text { PROFESSIONAL } \\
\text { COMMITMENT }\end{array}$} & $\begin{array}{l}\text { - The integral education of people is to be enhanced from a } \\
\text { cultural diversity point of view to attend the specificity of } \\
\text { every culture. "We must endeavour to understand and } \\
\text { integrate culturally different people. This means we, } \\
\text { as teachers, have to develop professionally and } \\
\text { personally". } \\
\text { The initial training of teachers must integrate } \\
\text { subjects-versing on dialogue and intercultural } \\
\text { understanding. "No doubt that working with people of } \\
\text { diverse origins enhances our professional culture". }\end{array}$ & $\begin{array}{l}\text { The culture of institutions must } \\
\text { promote the inclusion and respect of } \\
\text { migrant identities. Weight for this } \\
\text { factor is lower than } 0.64 \text {, though its } \\
\text { average is one of the highest } \\
\text { registered (5.33). } \\
\text { Teachers consider interculturality as } \\
\text { an integral educational function for } \\
\text { families and students. Weight for } \\
\text { the factor is of } 0.76 \text {. Average of } 4.82 \text {. }\end{array}$ \\
\hline & $\begin{array}{l}\text { The training actions performed by teachers need to } \\
\text { promote their professional developments and dialogue } \\
\text { with diverse cultures. Knowledge of other languages is } \\
\text { fundamental. } \\
\text { "Use of a flipped classroom methodology. Students from } \\
\text { Argelia speak about how to improve the cattle-raising } \\
\text { activities in their country. They evaluate concrete actions } \\
\text { like the actual slaughter rules of animals". } \\
\text { Some university teachers declare they have not } \\
\text { experienced or heard of any dialogue between } \\
\text { cultures-based practices used to improve their professional } \\
\text { development. } \\
\text { "I haven't heard of any specific training fomenting } \\
\text { dialogue between cultures at university though I had } \\
\text { experiences at previous educational stages". }\end{array}$ & $\begin{array}{l}\text { Teachers widen their professional } \\
\text { culture when fomenting the integral } \\
\text { education of people and their } \\
\text { cultural diversity. Factor weight } \\
\text { obtained is of } 0.91 \text {. The average } \\
\text { obtained is } 5.21 \\
\text { Teachers related their professional } \\
\text { development with that of migrants } \\
\text { represented in the school groups. } \\
\text { Factor weight is } 0.70 \text {, The average } \\
\text { obtained is } 4.2 \text {. }\end{array}$ \\
\hline
\end{tabular}

Table A5. Complementarity of data: Methodological Dimension.

\begin{tabular}{|c|c|c|}
\hline & Qualitative Analysis & Quantitative Analysis \\
\hline \multirow{2}{*}{ METHODOLOGICAL } & $\begin{array}{l}\text { - To attend all students' expectations inside the } \\
\text { group. "Why not considering all cultural } \\
\text { diversities represented inside the group?". } \\
\text { - Quality education must be adapted to students' } \\
\text { needs. "We need to develop a methodological } \\
\text { system that considers the cultural diversity } \\
\text { inside the class as an added value". }\end{array}$ & $\begin{array}{l}\text { - The attention to the cultural diversity of } \\
\text { students' needs be represented at all } \\
\text { fundamental stages of the teaching-learning } \\
\text { process. Value obtained after factorial } \\
\text { analysis is } 0.80 \text { The average is } 5.24 \text {. } \\
\text { - Teachers need to favor the experiences and } \\
\text { active exploration using works performed by } \\
\text { focus groups. Factorial analysis: } 0.63 \text {, one of } \\
\text { the lowest weights for this factor. The average } \\
\text { obtained is } 5.48 \text {. }\end{array}$ \\
\hline & $\begin{array}{l}\text { Use of a thesaurus and linguistic adapted } \\
\text { classes to foment students' inclusion. "Some } \\
\text { participants disagree on the linguistic } \\
\text { introduction classes for early and primary } \\
\text { education groups". "Active methodologies and } \\
\text { support provided during workshops and } \\
\text { cultural weeks. The implication of families and } \\
\text { teachers in the respect and intercultural } \\
\text { understanding-based activities is essential". }\end{array}$ & $\begin{array}{l}\text {-Fomenting the intercultural dialogue implies } \\
\text { that teachers must consider the social contexts } \\
\text { of groups: Values, beliefs, habits, } \\
\text { and expectations. } \\
\text { Value obtained with the factorial analysis } \\
\text { is } 0.86 \text {. } \\
\text { The average obtained in the descriptive } \\
\text { analysis is } 5.41 \text {. }\end{array}$ \\
\hline
\end{tabular}




\section{References}

1. Medina, R.A.; Domínguez, G.M.C.; Ribeiro, G.F. Formación del profesorado universitario en las competencias docentes. Rev. Hist. Educ. Latinoam. 2011, 13, 119-138.

2. Soto, A.D.; Avoro, N.M.T.; Ruiz-Cabezas, A.; Medina, R.A. Formación de docentes en Guinea Ecuatorial. Historias de vida de maestras en perspectiva al 2020. Rev. Hist. Educ. Latinoam. 2016, 18, 67-94.

3. Banks, J.A. Diversity and Citizenship Education in Multicultural Nations. Multicult. Educ. Rev. 2009, 1, 1-28. [CrossRef]

4. Nordén, B. Learning and Teaching Sustainable Development in Global-Local Contexts; Malmö Högskola, Fakulteten för Lärande Och Samhälle: Malmö, Sweden, 2016; ISBN 91-7104-625-9.

5. April, D.; D'Addio, A.C.; Kubacka, K.; Smith, W.C. Issues of Cultural Diversity, Migration, and Displacement in Teacher Education Programmes. 2018. Available online: https://www.semanticscholar.org/paper/Issues-ofCultural-Diversity\%2C-Migration\%2C-and-in-April-Addio/761378210f3ecd048b0a5c83583b1cfd42a732ac (accessed on 20 November 2020).

6. Deardorff, D.K.; Arasaratnam-Smith, L.A. Intercultural Competence in Higher Education: International Approaches, Assessment and Application; Routledge: Abingdon, UK, 2017; ISBN 1-315-52923-8.

7. Tomé, M.; Herrera, L.; Lozano, S. Teachers' opinions on the use of personal learning environments for intercultural competence. Sustainability 2019, 11, 4475.

8. Baldacci, M. La Scuola al Bivio: Mercato o Democrazia? Franco Angeli: Milano, Italy, 2019; ISBN 978-88-917-8111-6.

9. Baldacci, M. Dallo svantaggio sociale all'eguaglianza formativa. Rev. Derechos Hum. Educ. 2019, 1, 45-57.

10. Ruf, U.; Gallin, P. Dialogisches Lernen in Sprache und Mathematik. Band 2. Spuren Legen-Spuren Lesen. Unterricht Mit Kernideen und Reisetagebüchern. Seelze-Velber: Kallmeyer; Seelze-Velber: Kallmeyer, NY, USA, 1998.

11. Huber, G. Aprendizaje activo para el desarrollo de las instituciones educativas. In Desarrollo de Las Instituciones y su Incidencia en la Innovación de la Docencia; Universitas: Madrid, Spain, 2014; pp. 35-48. ISBN 978-84-7991-434-9.

12. Huber, G. Aprendizaje activo y metodologías educativas. Rev. Educ. 2008, 59-81. Available online: http://reforma. fen.uchile.cl/Papers/Active\%20learning\%20and\%20methods\%20of\%20teaching\%20-\%20Huber.pdf (accessed on 21 August 2020).

13. Shadiev, R.; Wang, X.; Huang, Y.M. Promoting Intercultural Competence in a Learning Activity Supported by Virtual Reality Technology. Int. Rev. Res. Open Distrib. Learn. 2020, 21, 157-174. [CrossRef]

14. Sykes, J. Technologies for teaching and learning intercultural competence and interlanguage pragmatics. Handb. Technol. Second Lang. Teach. Learn. 2017, 119-133. [CrossRef]

15. Le Boterf, G. Construire Les Compétences Individuelles et Collectives: Le Modèle: Agir Avec Compétence en Situation; Les Résponses à 100 Questions; Eyrolles: Paris, France, 2013; ISBN 978-2-212-55560-8.

16. Le Boterf, G. Développer la Compétence Des Professionnels; Éditions d'Organisation: Paris, France, 2003; ISBN 978-2-7081-2759-3.

17. Nurhadi, D.; Lyau, N.-M. A Conceptual Framework for the Development of Twenty-First Century Vocational Teachers' Professional Competencies. Int. Forum Teach. Stud. 2017, 13, 8-20.

18. Arasaratnam, L.A.; Doerfel, M.L. Intercultural communication competence: Identifying key components from multicultural perspectives. Int. J. Intercult. Relat. 2005, 29, 137-163. [CrossRef]

19. Ashwill, M.; Du'o'ng, T.H.O. Developing Globally Competent Citizens: The Contrasting Cases of the United States and Vietnam. In The Sage Handbook of Intercultural Competence; SAGE: London, UK, 2009; pp. 141-157, ISBN 978-1-4129-6045-8.

20. Maharaja, G. The Impact of Study Abroad on College Students' Intercultural Competence and Personal Development. Int. Res. Rev. 2018, 7, 18-41.

21. Perrenoud, P. Développer la Pratique Réflexive Dans le Métier D’enseignant Professionnalisation et Raison Pédagogique. 2010. Available online: https://journals.openedition.org/osp/4894\#quotation (accessed on 15 July 2020). [CrossRef]

22. Domínguez, G.M.C.; García, G.P. Tratamiento Didáctico de Las Competencias Básicas; Editorial Universitas: Madrid, Spain, 2012; ISBN 978-84-7991-389-2.

23. Medina Rivilla, A.; De la Herrán Gascón, A.; Dominguez Garrido, M.C. Hacia una Didáctica Humanista; UNED-Redipe: Madrid, Spain, 2020; ISBN 978-84-362-7642-8. 
24. Medina, D.M.C. Formación de Líderes en Inteligencia Emocional y Gestión Del Talento; Universitas: Madrid, Spain, 2015; ISBN 978-84-7991-442-4.

25. Day, C.; Gu, Q.; Sammons, P. The Impact of Leadership on Student Outcomes: How Successful School Leaders Use Transformational and Instructional Strategies to Make a Difference. Educ. Adm. Q. 2016, 52, 221-258. [CrossRef]

26. Acquaro, D. Preparing the Next Generation of Educational Leaders: Initiating a Leadership Discourse in Initial Teacher Education. Int. Stud. Educ. Adm. 2019, 47, 107-124.

27. Nissilä, S.-P.; Karjalainen, A.; Koukkari, M.; Kepanen, P. Towards competence-basedpractices in vocational education-What will the process require from teacher education and teacheridentities? CEPS J. 2015, 5, 13-34.

28. Eraut, M. Learning from other people in the workplace. Oxf. Rev. Educ. 2007, 33, 403-422. [CrossRef]

29. de Bruijn, E. Teaching in innovative vocational education in the Netherlands. Teach. Teach. 2012, 18, 637-653. [CrossRef]

30. Medina Rivilla, A.; Gómez Díaz, R.M.; Medina Domínguez, M.C.; González Fernández, R. Formación de líderes pedagógicos ante la complejidad de los institutos de educación secundaria. In Complejidad y Transversalidad: Construcciones y Reconfiguraciones Desde a Educación; Catellanos Editores: CDMX, Mexico, 2020; ISBN 978-607-98737-9-0.

31. Day, C.; Gu, Q.; e-Libro, C. Profesores Vidas Nuevas, Verdades Antiguas; Narcea: Madrid, Spain, 2014; ISBN 978-84-277-2003-9.

32. Schutz, P.A.; Francis, D.C.; Hong, J. Research on teacher identity: Introduction to mapping challenges and innovations. In Research on Teacher Identity; Springer: Berlin, Germany, 2018; pp. 3-9.

33. Dominguez Garrido, M.C.; Ruiz-Cabezas, A.; Medina Rivilla, A. Experiencias docentes y su proyección en la identidad profesional. Rev. Hist. Educ. Latinoam. 2017, 19, 111-133. [CrossRef]

34. Tellmann, S.M.; Røsdal, T.; Frølich, N. Professional educational programmes under pressure. Organizational challenges related to strengthening research. Stud. High. Educ. 2020, 1-11. [CrossRef]

35. Day, C. Professional identity matters: Agency, emotions, and resilience. In Research on Teacher Identity; Springer: Berlin, Germany, 2018; pp. 61-70.

36. Olsen, B.; Buchanan, R. "Everyone wants you to do everything": Investigating the professional identity development of teacher educators. Teach. Educ. Q. 2017, 44, 9-34.

37. Thomas, L.; Beauchamp, C. Understanding new teachers' professional identities through metaphor. Teach. Teach. Educ. 2011, 27, 762-769. [CrossRef]

38. Segura-Robles, A.; Parra-González, M.E. Analysis of teachers' intercultural sensitivity levels in multicultural contexts. Sustainability 2019, 11, 3137. [CrossRef]

39. Karousiou, C.; Hajisoteriou, C.; Angelides, P. Teachers' professional identity in super-diverse school settings: Teachers as agents of intercultural education. Teach. Teach. 2019, 25, 240-258. [CrossRef]

40. Van Lankveld, T.; Schoonenboom, J.; Volman, M.; Croiset, G.; Beishuizen, J. Developing a teacher identity in the university context: A systematic review of the literature. High. Educ. Res. Dev. 2017, 36, 325-342. [CrossRef]

41. Yinger, R.J. Enseñanza reflexiva y experiencias de aula en la formación del profesorado. In Pensamiento de Los Profesores y Toma de Decisiones; Universidad de Sevilla, Servicio de Publicaciones: Sevilla, Spain, 1986; pp. 113-141.

42. Paricio, J.; Fernández, A.; Fernández, I. Cartografía de la Buena Docencia Universitaria: Un Marco Para el Desarrollo Del Profesorado Basado en la Investigación; Universitas: Madrid, Spain, 2019; ISBN 978-84-277-2615-4.

43. Villa Sánchez, A. Aprendizaje Basado en Competencias: Desarrollo e implantación en el ámbito universitario. REDU Rev. Docencia Univ. 2020, 18, 19.

44. Zabalza Beraza, M.Á.; Zabalza Cerdeiriña, M.A.; De Côrte Victoria, M.I. Identidad profesiona del profesorado universitario. In Identidad Profesional Docente; Narcea: Madrid, Spain, 2018; pp. 141-157, ISBN 978-84-277-2396-2.

45. Junquera de Estéfani, R. Ética y Deontología Públicas; Universitas: Madrid, Spain, 2018; ISBN 978-84-7991-488-2.

46. Goleman, D. La práctica de la inteligencia emocional; Editorial Kairós: Madrid, España, 1999.

47. Ogay, T.; Edelmann, D. 'Taking culture seriously': Implications for intercultural education and training. Eur. J. Teach. Educ. 2016, 39, 388-400. [CrossRef] 
48. Portera, A.; Grant, C. Intercultural Education and Competences: Challenges and Answers for the Global World; Cambridge Scholars Publishing: Newcastle, UK, 2017; ISBN 1-4438-6266-5.

49. Biasutti, M.; Concina, E.; Frate, S. Social sustainability and professional development: Assessing a training course on intercultural education for in-service teachers. Sustainability 2019, 11, 1238. [CrossRef]

50. Trumbull, E.; Greenfield, P.M.; Rothstein-Fisch, C.; Maynard, A.E.; Quiroz, B.; Yuan, Q. From Altered Perceptions to Altered Practice: Teachers Bridge Cultures in the Classroom. Sch. Community J. 2020, 30, 243-266.

51. Biasutti, M.; De Baz, T.; Alshawa, H. Assessing the infusion of sustainability principles into university curricula. J. Teach. Educ. Sustain. 2016, 18, 21-40. [CrossRef]

52. Szelei, N.; Tinoca, L.; Pinho, A.S. Professional development for cultural diversity: The challenges of teacher learning in context. Prof. Dev. Educ. 2020, 46, 780-796. [CrossRef]

53. Melé, D. Ethical Education in Accounting: Integrating Rules, Values and Virtues. J. Bus. Ethics 2005, 57, 97-109. [CrossRef]

54. Frimberger, K. The ethics of performative approaches in intercultural education. In Going Performative Interculture Education; Multilingual Matters: Bristol, UK, 2017; pp. 21-40.

55. Jokikokko, K.; Uitto, M. The significance of emotions in Finnish teachers' stories about their intercultural learning. Pedagogy Cult. Soc. 2017, 25, 15-29. [CrossRef]

56. Rogers, E.M.; Hart, W.B. The Histories of Intercultural, International, and Development Communication. In Handbook of International and Intercultural Communication; Sage Publications: Thousand Oaks, CA, USA, 2002; pp. 1-18.

57. Medina Rivilla, A. Formación Del Profesorado: Actividades Innovadoras Para el Dominio de Las Competencias Docentes; Universitas: Madrid, Spain, 2013; ISBN 978-84-9961-131-0.

58. Domínguez Garrido, M.C.; Medina Rivilla, A.; López Gómez, E. Desarrollo de competencias en el primer curso de universidad: Estudio de caso. Publicaciones 2018, 48, 39-62. [CrossRef]

59. Rissanen, I.; Kuusisto, E.; Kuusisto, A. Developing teachers' intercultural sensitivity: Case study on a pilot course in Finnish teacher education. Teach. Teach. Educ. 2016, 59, 446-456. [CrossRef]

60. Umarov, K.A. Innovative methods of improving professional and pedagogical competencies of future teachers. Eur. J. Res. Reflect. Educ. Sci. 2020, 8, 46-50.

61. Huber, G.; García González, P. El aprendizaje transversal, integrado e intercultural y los métodos de enseñanza para el aprendizaje adaptado a la complejidad. In Didáctica General: Formación Básica Para Los Profesionales de la Educación; Universitas: Madrid, Spain, 2015; pp. 117-168. ISBN 978-84-7991-445-5.

62. Domínguez Garrido, M.C.; Medina Domínguez, M.d.C.; Martínez Sánchez, M.I. Metodología de Investigación Para la Educación y la Diversidad; UNED—Universidad Nacional de Educación a Distancia: Salamanca, Spain, 2018; ISBN 978-84-362-7484-4.

63. Hamilton, L.; Corbett-Whittier, C. Using Case Study in Education Research; Research Methods in Education; SAGE: Los Angeles, CA, USA; London, UK, 2013; ISBN 978-1-4462-0816-8.

64. Morin, E. Introducción al Pensamiento Complejo; Gedisa: Barcelona, Spain, 2011; ISBN 978-84-7432-518-8.

65. Medina Rivilla, A.; Pérez Navío, E.; Medina Domínguez, M.C. Formación de Líderes y Directivos Para el Desarrollo Sustentable de Las Organizaciones e Instituciones; Universitas: Madrid, Spain, 2018; ISBN 978-84-7991-502-5.

66. Gento Palacios, S. Conceptualización y dimensiones del liderazgo educativo. In Desarrollo de Las Instituciones y su Incidencia en la Innovación de a Docencia; Universitas: Madrid, Spain, 2014; pp. 190-201.

67. González Fernández, R.; Palomares Ruiz, A.; López Gómez, E.; Gento Palacios, S. Explorando el liderazgo pedagógico del docente: Su dimensión formativa. Context. Educ. Educ. 2019, 24, 9-25. [CrossRef]

68. MacGregor, S.K.D.; Esmail, H.W. Embracing Student Diversity: Developing Intercultural Competence With ICT. In Promoting Ethnic Diversity and Multiculturalism in Higher Education; IGI Global: Hershey, PA, USA, 2018; pp. 1-23.

69. Barreto, C.R.; Haydar, J.M. Pedagogical Intercultural Practice of Teachers in Virtual Environments. Turk. Online J. Distance Educ. 2016, 17, 190-202.

70. Austin, R.; Rickard, A.; Reilly, J. Face-to-face contact in blended learning for intercultural education: The role of teachers. Ir. Educ. Stud. 2017, 36, 323-340. [CrossRef]

71. Rees, W.; Wackernagel, M. Ecological footprins and appropriated carrying capacity: Measuring the natural capital requirements of the human economy. In Investing in Natural Capital: The Ecological Economics Approach to Sustainability; ISLAND PRESS: Washington, DC, USA, 1994; pp. 362-391, ISBN 1-55963-316-6. 
72. Meadows, D.; Randers, J.; Meadows, D. Limits to Growth: The 30-Year Update; Chelsea Green Publishing: Junction, VT, USA, 2004; ISBN 1-60358-155-3.

73. Creswell, J.W.; Clark, V.L.P. Designing and Conducting Mixed Methods Research; Sage Publications: Thousand Oaks, CA, USA, 2017; ISBN 1-4833-4701-X.

74. Gibson, C.B. Elaboration, generalization, triangulation, and interpretation: On enhancing the value of mixed method research. Organ. Res. Methods 2017, 20, 193-223. [CrossRef]

75. Medina Rivilla, A.; Ruiz-Cabezas, A.; Pérez Navío, E.; Medina Domínguez, M.C. Diagnóstico de un programa de formación de docentes en competencias para el primer año de universidad. Aula Abierta 2019, 48, 239-250. [CrossRef]

76. Ruiz Cabezas, A.; Medina Domínguez, M.D.C.; Pérez Navío, E.; Medina Rivilla, A. University teachers' training: The Digital competence. Píxel-Bit Rev. Medios Educ. 2020, 58, 181-215.

77. Tashakkori, A.; Teddlie, C. SAGE Handbook of Mixed Methods in Social \& Behavioral Research; SAGE Publications, Inc.: Thousand Oaks, CA, USA, 2010; ISBN 978-1-4129-7266-6.

78. Levitt, H.M.; Bamberg, M.; Creswell, J.W.; Frost, D.M.; Josselson, R.; Suárez-Orozco, C. Journal article reporting standards for qualitative primary, qualitative meta-analytic, and mixed methods research in psychology: The APA Publications and Communications Board task force report. Am. Psychol. 2018, 73, 26-46. [CrossRef] [PubMed]

79. Huber, G. Investigación en la comunicación didáctica. In Fronteras en la Investigación de la Didáctica; Antonio, M.R., Concepción, D.G.M., De la Herrán Gascón, A., Eds.; UNED: Madrid, Spain, 2014; pp. 73-114. ISBN 978-84-362-6833-1.

80. Maxwell, J.A. The importance of qualitative research for causal explanation in education.h. Qual. Inq. 2012, 8, 655-661. [CrossRef]

81. Ziskin, M.B. Critical discourse analysis and critical qualitative inquiry: Data analysis strategies for enhanced understanding of inference and meaning. Int. J. Qual. Stud. Educ. 2019, 32, 606-631. [CrossRef]

82. Tavory, I. Interviews and Inference: Making Sense of Interview Data in Qualitative Research. Qual. Sociol. 2020, 43, 1-17. [CrossRef]

83. Dominguez Garrido, M.C.; Medina Domínguez, M.d.C.; Medina Rivilla, A. Formación del profesorado para el encuentro y diálogo entre culturas. In Nuevas Perspectivas en la Formación de Los Profesores; UNED: Madrid, Spain, 2017; pp. 219-264.

84. Domínguez Garrido, M.C. Investigación y Formación Del Profesorado en Una Sociedad Intercultural; UNED: Madrid, Spain, 2006; ISBN 978-84-7991-191-1.

85. Bastos, M.; Araújo e Sá, H. Pathways to teacher education for intercultural communicative competence: Teachers' perceptions. Lang. Learn. J. 2015, 43, 131-147. [CrossRef]

86. Avoro Nguema, M.T.; Ruiz-Cabezas, A. Necesidades de formación del profesorado en la competencia intercultural en Malabo, Guinea Ecuatorial. Indivisa Bol. Estud. E Investig. 2016, 16, 105-126.

87. Ashwin, P.; Abbas, A.; McLean, M. Conceptualising transformative undergraduate experiences: A phenomenographic exploration of students' personal projects. Br. Educ. Res. J. 2016, 42, 962-977. [CrossRef]

88. Paulsen, M.B.; Perna, L.W. (Eds.) Higher Education: Handbook of Theory and Research: Volume 34; Higher Education: Handbook of Theory and Research; Springer International Publishing: Cham, Switzerlands, 2019; Volume 34, ISBN 978-3-030-03456-6.

89. Stern, D.; Huber, G.L. (Eds.) Active Learning for Students and Teachers: Reports from Eight Countries; P. Lang: Frankfurt am Main, Germany; New York, NY, USA, 1997; ISBN 978-3-631-30824-0.

90. Martínez, P. Interculturalidad e islam. In Interculturalidad, Formación del Profesorado y Educación; Pearson Educación: Madrid, Spain, 2005; pp. 1-12, ISBN 84-205-4427-2.

91. Leeman, Y.; van Koeven, E. New immigrants. An incentive for intercultural education? Educ. Inq. 2019, 10, 189-207. [CrossRef]

Publisher's Note: MDPI stays neutral with regard to jurisdictional claims in published maps and institutional affiliations. 